\title{
Pengamatan makroskopik dan mikroskopik membran melalui pengukuran konduktansi dan kapasitansi listrik dalam larutan elektrolit
}

\author{
Kiagus Dahlan \\ Divisi Biofisika, Departemen Fisika, \\ Fakultas Matematika dan Ilmu Pengetahuan Alam, IPB University, Bogor
}

\begin{abstract}
Abstrak Telah dilakukan pengukuran konduktansi dan kapasitansi membran bawang bombay dan membran salak pondoh. Membran bawang bombay diberi dua perlakukan berbeda, yaitu direndam dalam air murni selama 12 jam, dan tanpa direndam. Pengukuran dilakukan secara langsung tanpa menggunakan larutan elektrolit dan dengan menggunakan larutan elektrolit. Pengukuran konduktansi membran dalam larutan elektrolit dilakukan pada berbagai frekuensi dan suhu, serta dengan variasi konsentrasi dan valensi ion larutan. Larutan elektrolit yang digunakan adalah $\mathrm{MgCl} 2$ dan $\mathrm{NaCl}$. Hasilnya memperlihatkan bahwa membran bawang bombay yang direndam selama 12 jam mengalami peningkatan kapasitansi listrik dan penyempitan pori yang ditandai oleh naiknya energi aktivasi ion. Perhitungan yang dilakukan menunjukkan bahwa rataan radius pori membran tanpa direndam dan yang direndam berturut-turut adalah sekitar $2 \mathrm{~nm}$ dan $0.13 \mathrm{~nm}$. Pengukuran konduktansi membran salak pondoh menggunakan berbagai konsentrasi dan valensi ion memperlihatkan bahwa konduktansi membran dalam larutan elektrolit meningkat sesuai dengan peningkatan konsentrasi dan valensi ion larutan.
\end{abstract}

Kata Kunci:, kapasitansi, larutan elektrolit, membran

\section{PENDAHULUAN}

Konduktansi listrik merupakan ukuran cepat lambatmya arus listrik mengalir pada suatu bahan (material) jika bahan tersebut diberi beda tegangan. Kemampuan bahan mengalirkan arus disebut konduktivitas bahan. Pada bahan yang bersifat padatan, seperti logam, arus listrik dibawa oleh elektron bebas uyang ada pada bahan tersebut. Tetapi, pada cairan, seperti larutan elektrolit, arus listrik dibawa oleh ionion. Semakin banyak jumlah ion akan semakin besar pula arus yang dihasilkannya. Besarnya arus listrik pada larutan elektrolit juga berbanding lurus dengan jenis elektrolit (valensi dan sifat kelarutan) yang digunakan, suhu lingkungan, dan tentu saja besar kecilnya tegangan yang diberikan.

Membran dapat dideskripsikan sebagai sebuah lapisan atau lembaran tipis yang berperan sebagai batas selektif antara dua fasa. Mekanisme seleksinya bisa karena ukuran dan distribusi ukuran pori atau bisa juga karena medan elektrostatik yang ditimbulkan oleh muatan listrik yang ada pada membran tersebut. Secara umum, membran dapat dikelompokkan menjadi dua, yaitu membran alami dan membran sintetik. Membran alami atau membran biologi pada dasarnya adalah membran yang menyelimuti sel, baik sel otot maupun sel saraf, pada makhluk hidup. Tetapi membran alami bisa juga berupa selaput tipis yang menyelimuti bagian tertentu atau keseluruhan bahan biologi, seperti membran telur (selaput tipis yang menyelimuti telur yang menempel pada bagian dalam cangkang telur), dan membran salak (selaput tipis yang meyelimuti buah salak yang menempel pada bagian dalam kulit salak). Membran sintetik adalah membran buatan yang dapat dibuat dari bahan-bahan organik maupun anorganik seperti polimer, gelas, keramik, dll.). Membran sintetik ada yang dibuat sebagai tiruan untuk mempelajari membran biologi, walaupun utamanya tujuan pembuatan membran sintetik adalah untuk diaplikasikan dalam proses filtrasi atau purifikasi dalam teknologi membran.

Sifat listrik membran biologi dan membran sintetik banyak dipelajari [1-3]. Salah satu cara yang dapat dilakukan adalah melalui pengukuran konduktansi dan kapasitansinya. Konduktansi dan kapasitansi listrik membran dapat diukur secara langsung, dan dapat pula diukur di dalam larutan elektrolit [4,5]. Jika sebuah membran diletakkan dalam sebuah chamber yang dilengkapi dengan elektroda arus dan tegangan, sebagaimana terlihat pada Gambar 1, lalu diisi larutan elektrolit dan diberi beda tegangan, maka konduktansinya dapat diukur. Membran dalam hal ini akan berfungsi sebagai penghambat gerakan ion dalam larutan, sehingga konduktasi larutan akan berbeda ketika 
ada dan tidak ada membran. Melalui pengukuran ini ternyata bisa didapatkan informasi makroskopik dan mikroskopik dari membran yang diamati. Pada tulisan ini akan dipaparkan beberapa hasil pengukuran konduktansi dan kapasitansi listrik membran biologi dalam larutan elektrolit, estimasi ukuran pori yang didapatkan serta potensi pengembangan aplikasi metoda ini.

\section{LANDASAN TEORI}

Berdasarkan konsep elektromagnetika, setiap ion mempunyai energi-diri (self-energy), karena adanya interaksi elektrostatik degan lingkungan, yang besarnya bergantung pada sifat permitivitas lingkungan (medium) tempat ion tersebut berada [6,7]. Ketika sebuah ion berada di dalam pori tentu energi-dirinya lebih besar dibandingkan ketika berada di luar pori. Perbedaan energi-diri ini, biasa dinyatakan sebagai energy barrier membran atau energi aktivasi ion, dan dapat dinyatakan sebagai

$$
\Delta U=\frac{z^{2} q^{2} \alpha}{4 \pi \varepsilon_{0} \varepsilon_{m} r}
$$

dengan $r$ menyatakan radius pori membran (m), $z$ merupakan bilangan valensi ion $q$ adalah muatan elektron, $\alpha$ adalah konstanta geometri yang besarnya bergantung sifat dielektrik lingkungan, $\varepsilon_{o}$ menyatakan permitivitas ruang hampa, dan $\varepsilon_{m}$ adalah konstanta dielektrik membran.

Tingginya energi-diri ion ketika berada di dalam pori membran tentu, secara energetika, bukanlah kondisi yang disukai oleh ion tersebut. Oleh karena itu, untuk dapat melewati membran, ion memerlukan tambahan energi, yaitu dari energi listrik yang diberikan oleh sumber tegangan.

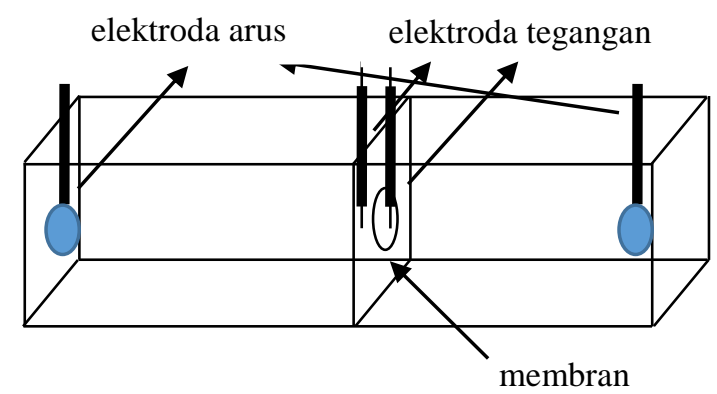

Gambar 1. Chamber untuk pengamatan konduktasi dan kapasitansi membran dalam larutan elektrolit

Dengan menerapkan pola distribusi Maxwell-Boltzman untuk distribusi ion di dalam dan di luar pori [8], dan karena konduktansi listrik larutan berbanding lurus dengan konsentrasi, maka dapat dituliskan

$$
G=G o \exp (-\Delta U / k T)
$$

dengan $G$ merupakan konduktansi larutan di dalam pori membran dan Go adalah konduktansi larutan di luar pori pada jarak yang jauh dari membran.

Nilai $G$ ditentukan oleh beberapa faktor diantaranya geometri pori, konsentrasi pori dan mobilitas ion. Jika medan listrik dalam pori konstan, maka besarnya nilai konduktansi G untuk tiap pori adalah

$$
G=\frac{q^{2} C_{0}\left(z_{p} a_{p} D_{p}+z_{n} a_{n} D_{n}\right) \pi r^{2}}{k T L}
$$

dengan $L$ adalah ketebalan membran, $k$ adalah konstanta Boltzmann, $T$ merupakan suhu dalam Kelvin, $z_{p}$ valensi ion positif, $z_{n}$ adalah valensi ion negatif, $a_{p}$ fraksi ion positif, dan $a_{n}$ fraksi ion negatif dalam pori.

\section{METODE PENELITIAN}

Pengukuran konduktansi dan kapasitansi membran secara langsung tanpa menggunakan larutan elektrolit dilakukan dengan menempatkan membran ke dalam chamber yang sudah dilengkapi dengan plat elektroda. Konduktansi dan kapasitansi membran kemudian diukur menggunakan LCR meter model Hioki 300.

Untuk pengukuran dalam larutan, alat yang digunakan adalah sebuah chamber, sebagaimana terlihat pada Gambar 1, yang sudah dilengkapi dengan elektroda arus dan elektroda tegangan. Di dalam chamber kemudian diletakkan sebuah membran, lalu chamber diisi dengan larutan elektrolit. Setelah sistem ini dihubungkan dengan sebuah sumber tegangan, maka ion-ion akan mengalir dari satu sisi chamber ke sisi lainnya menembus pori-pori membran. Larutan garam yang digunakan adalah $\mathrm{NaCl}$ dan $\mathrm{MgCl}_{2}$ pada berbagai konsentrasi. Membran yang digunakan adalah membran biologi, yaitu membran bawang bombay (kulit tipis yang menyelimuti bawang bombay) dan membran salak (kulit tipis yang menyelimuti buah salak). Untuk menghitung energi aktivasi ion menembus pori membran dilakukan pengukuran konduktansi pada berbagai suhu. Chamber dimasukkan ke dalam water bath lalu suhunya divariasikan. 


\section{HASIL DAN PEMBAHASAN}

\section{Pengamatan Makroskopik}

Konduktansi sebuah komponen atau suatu material murni yang hanya memiliki satu nilai kondiktivitas tidak bervariasi terhadap frekuensi. Tetapi jika material tersebut kompleks yaitu mengandung lebih dari satu nilai konduktivitas dan permitivitas listrik, maka konduktansi dan kapasitansinya bervariasi terhadap frekuensi. Gambar 2 dan 3 memperlihatkan kapasitansi dan konduktasi membran bawang bombay sebagai fungsi dari frekuensi yang diukur secara langsung, tanpa medium larutan elektrolit.

Pada penelitian ini dilakukan pengukuran konduktasi dan kapasitnsi membran bawang bombay yang telah diberi dua perlakuan yang berbeda, yaitu membran tanpa direndam terlebih dahulu dan membran yang direndam dalam air murni selama 12 jam. Hasilnya, sebagaimana terlihat pada Gambar 2, setelah direndam ternyata nilai kapasitansinya meningkat. Sementara nilai konduktansinya, sebagaimana diperlihatkan Gambar 3, tidak teramati adanya perubahan.

Nilai kapasitansi berbanding lurus dengan konstanta dielektrik bahan. Hasil yang ditunjukkan oleh Gambar 2 mengindikasikan adanya kenaikan permitivitas membran setelah direndam dalam air selam 12 jam. Hal ini menunjukkan adanya air yang terserap dalam membran, sehingga terbentuk sususnan paralel kapasitor yang menghasilkan kenaikan nilai kapasitansi. Konstanta dielektik air jauh lebih besar daripada konstanta dielektrik kulit bawang bombay yang berharga sekitar 30-40. Kesimpulan ini bersesuaian juga dengan hasil pengamatan fisik bahwa membran bawang bombay setelah direndam dalam air berkurang sifat lenturnya yang kemungkinan karena sudah banyak terisi air.

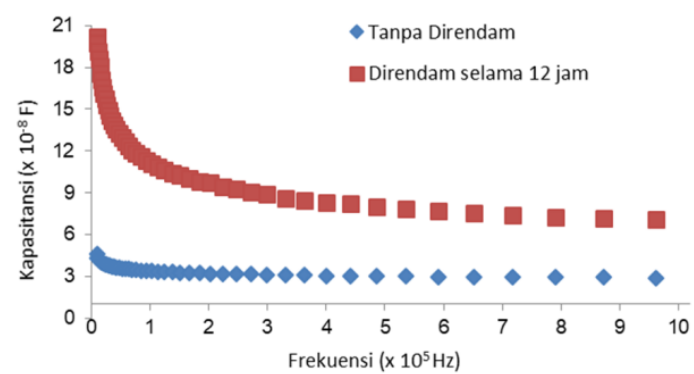

Gambar 2.Grafik perbandingan nilai kapasitansi membran bawang bombay tanpa direndam dan yang direndam selama 12 jam.
Sementera itu, pada Gambar 3 terlihat bahwa nilai konduktansi kedua membran tersebut tidak teramati mengalami perubahan. Hal ini menunjukkan bahwa, walaupun membran yang direndam sudah banyak terisi air sebagaimana didapat dari pengukuran kapasitansi, tetapi nilai konduktansinya tidak berubah. Air yang digunakan untuk merendam membran adalah air murni yang tidak atau sangat sedikit mengandung ion, sehingga tidak mempengaruhi sifat konduktivitas membran.

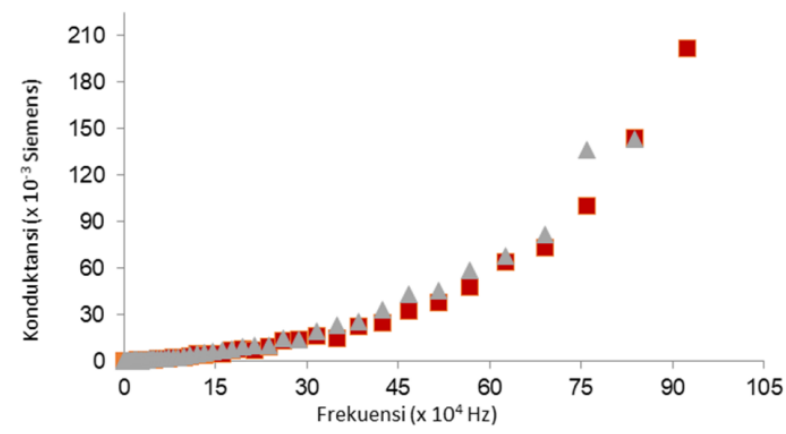

Gambar 3. Grafik konduktansi membran bawang bombay tanpa direndam dan yang direndam selama 12 jam.

Pada pengukuran dalam larutan elektrolit, konduktansi membran meningkat dengan semakin besarnya konsentrasi larutan eksternal. Variasi konsentrasi larutan eksternal menentukan jumlah ion dalam larutan tersebut. Semakin besar konsentrasinya maka semakin banyak pula jumlah ion dalam larutan. Berdasarkan Gambar 4 terlihat bahwa konduktansi membran salak pondoh meningkat dengan meningkatnya konsentrasi larutan eksternal. Pada Gambar 4 ditunjukkan juga pengaruh valensi ion. Konduktansi membran salak pondoh dalam larutan $\mathrm{MgCl}_{2}$ lebih besar daripada konduktansinya dalam larutan $\mathrm{NaCl}$ karena valensi ion $\mathrm{Mg}^{2+}$ lebih besar daripada valensi ion $\mathrm{Na}^{+}$.

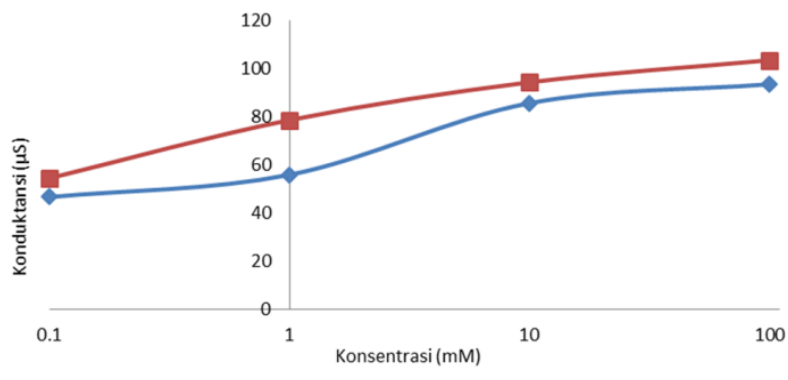

Gambar 4. Konduktansi membran salak pondoh pada berbagai konsentrasi larutan $\mathrm{NaCl}$ dan $\mathrm{MgCl}_{2}$ yang diamati pada suhu ruang. 


\section{Pengamatan Mikroskopik}

Pengamatan yang lebih mikroskopik didapatkan melalui penghitungan energi aktivasi ion ketika melewati membran. Nilai energi tersebut dapat dicari melalui kurva $\ln G$ terhadap 1/T yang didapatkan dari pengukuran konduktansi listrik pada berbagai suhu.

Dari persamaan (2) akan diperoleh hubungan yang linier antara $\ln G$ terhadap $1 / T$, yaitu $\ln G$ $=\ln G o-\Delta U / k T$. Jika dibuat plot $\ln G$ terhadap 1/T maka ln Go merupakan perpotongan ke dua sumbu, sedangkan kemiringan garis adalah $\Delta U / k$. Gambar 5 memperlihatkan plot data yang dihasilkan dari pengukuran konduktansi membran bawang bombay yang menunjukkan sebuah garis lurus dengan kemiringan negatif. Nilai kemiringan tersebut sebanding dengan nilai energi barrier atau energi aktivasi ion. Untuk membran tanpa direndam dan membran yang direndam berturut-turut didapat energi aktivasinya sebesar $\quad 7,67 \times 10^{-21} \mathrm{~J}$ dan $1,22 \times 10^{-19} \mathrm{~J}$.

Gambar 5 memperlihatkan bahwa energi aktivasi yang diperlukan ion untuk melewati membran yang sudah direndam selama 12 jam ternyata lebih besar dibandingkan dengan energi aktivasi untuk melewati membran yang tidak terlebih dahulu direndam. Temuan ini juga mengindikasikan bahwa pori-pori membran setelah direndam mengalami penyempitan. Hal ini sesuai dengan interpretasi yang sudah dikemukanakan sebelumnya bahwa setelah direndam selama 12 jam sejumah air terserap pada membran bawang bomba, sehigga poriporinya mengalami penyempitan. Dengan menggunakan persamaan (1) rataan jari-jari pori membran diperoleh untuk membran tanpa direndam dan yang direndam berturut-turut adalah $2 \mathrm{~nm}$ dan $0,13 \mathrm{~nm}$.

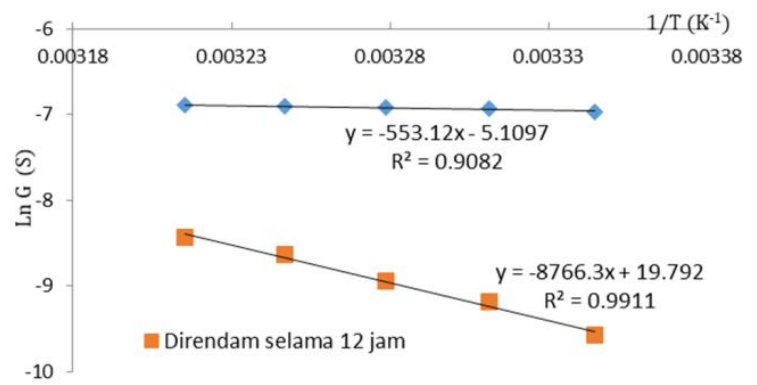

Gambar 5. Grafik hubungan antara suhu terhadap konduktansi membran bawang bombay tanpa direndam dan yang direndam selama 12 jam
Gambar 6 memperlihatkan hasil pengukuran konduktansi listrik membran salak pondoh dalam larutan $\mathrm{MgCl}_{2}$ dengan konsentrasi 0,1 $\mathrm{mM}, 1 \mathrm{mM}, 10 \mathrm{mM}$, dan $100 \mathrm{mM}$. Terlihat bahwa kemiringan kurva hampir sama pada konsentrasi larutan yang berbeda. Kemiringan kurva yang sama juga didapatkan ketika digunakan larutan elektrolit dengan valensi ion yang berbeda. Hal ini mengindikasikan bahwa membran salak pondoh yang diamati pada penelitian ini tidak bermuatan. Jika pori membran bermuatan, maka ion-ion yang berbeda valensinya atau berbeda konsentrasinya tentu memerlukan energi aktivasi yang berbeda pula ketika melintasi membran.

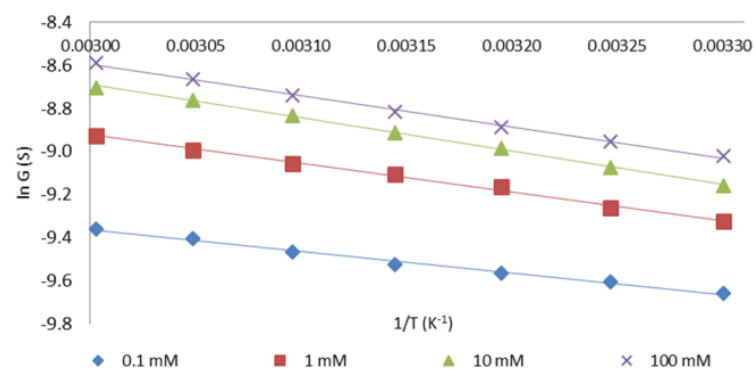

Gambar 6. Grafik $\operatorname{lnG}$ terhadap $1 / \mathrm{T}$ membran salak pondoh dalam larutan $\mathrm{MgCl}_{2}$ untuk 4 nilai konsentrasi yang berbeda yang diukur pada rentang suhu (30-60) ${ }^{0} \mathrm{C}$.

\section{Potensi Pengembangan: Mekanisme Penyumbatan Pori}

Penyumbatan (pore blocking) pada pori membran merupakan salah satu masalah utama dalam teknologi membran. Banyak penelitian telah dilakukan untuk mempelajari dan mengatasinya [9-11]. Penyumbatan dapat menyebabkan laju fluks larutan turun secara drastis. Lebih dari itu, penyumbatan juga dapat mengubah pola filtrasi atau purifikasi karena berubahnya ukuran pori atau distribusi ukuran pori. Penyebab terjadinya penyumbatan bisa karena adaya interaksi listrik atau kimia antara filtrat dan membran, bisa juga karena sifat permukaan membran akibat adanya variasi ukuran pori.

Melalui pengukuran konduktansi pada beragai suhu dapat diamati bagaimana proses penyumbatan berlangsung. Penyumbatan bisa dikelompokkan dalam 2 katagori, yaitu penyumbatan parsial dan penyumbatan penuh. Penyumbatan parsial adalah penyumbatan pada dinding pori tetapi tidak sampai menutup penuh lubang pori. Penyumbatan parsial dapat terjadi karena banyaknya filtrat yang melewati pori 
yang besar sehingga sebagian filtrat menempel pada dinding pori. Akibatnya diameter pori mengecil. Penyumbatan penuh adalah penyumbatan yang menutupi pori secara penuh sehingga filtrat tidak bisa lagi melewati pori tersebut. Penyumbatan penuh daat terjadi karena banyaknya filtrat yang menumpuk di permukaan membran sehingga menutupi pori-pori yang kecil. Akibatnya jumlah pori berkurang.

Dengan mengukur konduktansi membran pada berbagai suhu sebelum dan sesudah filtrasi, dan membuat plot $\ln G$ terhadap $1 / T$, maka akan didapat kemungkinan hasilnya sebagai berikut: i) Jika terjadi penyumbatan parsial pada pori-pori yang kecil dan atau poripori yang besar, maka energi aktivasi ion akan membesar; ii) Jika terjadi penyumbatan penuh pada pori-pori yang kecil, maka energi aktivasi ionnya akan mengecil karena diameter pori ratarata membesar. Jika pengamatan ini dilakukan pada beberapa selang waktu selama proses filtrasi, maka mekanisme penyumbatan bisa didapatkan.

Pengamatan mikroskopik ini tanpa merusak karena tanpa perlakuan apapun terhadap membran yang diamti. Membran diukur konduktansi listriknya pada rentang suhu tertentu. Batas minimum dan maksimum suhu yang digunakan tentu saja dapat diatur disesuaikan dengan daya tahan membran terhadap suhu. Berbeda halnya kalau pengamatan menggunakan SEM (scanning electron microscope). Sampel yang akan diamati harus diberi perlakuan pelapisan terlebih dahulu agar lebih konduktif, dan tentu hal ini sangat sulit dilakukan kalau yang diamati adalah membran biologi.

\section{KESIMPULAN DAN SARAN}

ada penelitian ini telah dilakukan pengukuran konduktansi dan kapasitansi membran bawang bombay yang telah diberi dua perlakuan yang berbeda, yaitu membran bawang bombay tanpa direndam dan membran bawang bombay yang direndam dalam air murni selama 12 jam. Hasilnya menunjukkan bahwa setelah direndam ternyata nilai kapasitansinya meningkat, sedangakn nilai konduktansinya tidak mengalami perubahan. Hasil pengamatan ini mengindikasikan bahwa membran yang direndam sudah banyak menyerap air. Kesimpulan ini juga dikuatkan oleh hasil pengukuran konduktansi pada berbagai suhu yang menunjukkan bahwa pori membran bawang bombay mengalami penyempitan setelah direndam selama 12 jam akibat banyaknya air yang diserap membran. Dari hasil perhitungan didapatkan bahwa rataan radius pori membran tanpa direndam dan yang direndam berturut-turut adalah sekitar $2 \mathrm{~nm}$ dan $0,13 \mathrm{~nm}$.

Pada penelitian ini juga telah dilakukan pengukuran konduktansi membran salak pondoh menggunakan berbagai konsentrasi dan valensi ion. Hasilnya adalah bahwa konduktansi membran dalam larutan elektrolit meningkat sesuai dengan peningkatan konsentrasi dan valensi ion larutan. Tetapi dari kurva $\ln G$ terhadap $1 / \mathrm{T}$ didapatkan kemiringanya relatif sama yang mengindikasikan bahwa membran salak pondoh yang diamati pada penelitian ini relatif tidak bermuatan.

Pengukuran konduktansi pada berbagai suhu ini dapat pula diaplikasikan pada proses filtrasi untuk mengamati bagaimana terjadinya penyumbatan pada membran selama berlangsungnya filtrasi. Penyumbatan pori pada dasarnya bisa dikelompokkan dalam 2 katagori, yaitu penyumbatan parsial dan penyumbatan penuh. Penyumbatan parsial mengakibatkan ukuran pori rata-rata mengecil, sedangkan penyumbatan penuh pada pori membran berukuran kecil akan mengahsilkan ukuran pori rata-rata yag membesar.

\section{UCAPAN TERIMA KASIH}

Penulis mengucapkan terima kasih kepada mahasiswa Program Magister Biofisika Institut Pertanian Bogor karena data yang digunakan pada tulisan ini merupakan hasil seleksi terhadap laporan praktikum mata kuliah Biofisika Membran yang diasuh penulis.

\section{DAFTAR PUSTAKA}

[1] H. D. Herce and A. E. Garcia, "Cell penetrating peptides: how do they do it?", Journal of Biological Physics, 33 (2007) 345-356.

[2] D. Schmidt, Q. X. Jiang and R. MacKinnon. "Phospholipids and the origin of cationic gating charges in voltage sensors", Nature, 444 (2006) 775-779.

[3] S. H. Chung, O. S. Andersen and V. Krishnamurthy, Biological Membrane Ion Channels: Dynamics, Structure, and Applications, Springer, 2007. 
[4] J. Juansah, I. W. Budiastra, K. Dahlan and K. B. Seminar, "Electrical Properties of Garut Citrus Fruits at Low Alternating Current Signal and its Correlation with Physicochemical Properties During Maturation", International Journal of Food Properties, 17 (7) (2014) 1498-1517

[5] W. Maulina , J. Juansah and K. Dahlan, The electrical conductance studies on the chicken-egg membrane in presence of alkali chlorides, IOP Conference Series: Earth and Environmental Science, 187 (2018) 012011

[6] R. M. Guljarani, Bioelectricity and Biomagnetism, John Wiley \& Sons, 1998.

[7] H. T. Tien and A. Ottova-Leitmannova, Membrane Biophysics, Elsevier, 2000.
[8] M. Hoch, Statistical and Thermal Physics: An Introduction, CRC Press, 2011.

[9] S. Meng et al., "Membrane fouling and performance of flat ceramic membranes in the application of drinking water purification", Water, 11(2606) (2019) 1-16

[10] H. A. Maddah et al., "Evaluation of various membrane filtration modules for the treatment of seawater". Applied Water Science, 8(150) (2018)

[11] Q. F. Alsalhy, T. M. Albyati and M. A. Zablouk, "A study of the effect of operating conditions on reverse osmosis membrane performance with and without air sparging technique", Chemical Engineering Comunications, 200 (2013) 1-19. 